\title{
Pancreatic surgery in elderly patients
}

\author{
U Prati, L Roveda, R De Vinci, V Diaco, M G Fava, M Renne, A Straticò, G Vescio, D Voci \\ From de Senectute: Age and Health Forum \\ Catanzaro, Italy. 5-7 December 2009
}

\section{Background}

Elderly pts are at a greater risk of post-operative complications than younger ones, due to several pre-existing co-morbidities.

Nevertheless, in recent years, improvements in surgical techniques and mainly in anesthesiology have allowed successful treatments also in elderly people.

\section{Materials and methods}

122 pts (M: 65; F: 57), over 70 years of age, affected with pancreatic pathologies, were considered. Pre-existing comorbidities were mainly represented by: hypertension, chronic obstructive pulmonary disease, diabetes mellitus, coronary artery disease, cardiac valve disease.

Percutaneous and or endoscopic US-guided biopsy of the pancreas for histopathologic demonstration of cancer before surgery or chemotherapy was always performed.

88 pts suffered from cancer of the pancreas; 6 from benign tumors of the pancreas; 26 from pancreatitis; 1 from cancer of the transverse colon infiltrating the pancreas and the stomach and 1 from cancer of the stomach infiltrating the head of the pancreas.

\section{Results}

92 pts underwent surgery and were thus divided: 67 for cancer, 7 for benign pathologies and 18 for pancreatitis; 53 pts underwent pancreatic resections and were thus divided: 1 total pancreatectomy, 10 distal splenopancreatectomies, 19 pancreaticoduodenectomies, 23 partial resections. 24 pts underwent surgical palliation for unresectable cancer, conditioning obstructive jaundice and or duodenal obstruction. 3 pts underwent intraoperative biopsy.

25 pts with obstructive jaundice, underwent ERCP, with positioning of endo-luminal stent before surgery or before chemotherapy (if resective surgery was contraindicated).

\footnotetext{
Oncologic Surgery Unit - Cancer Center of Excellence, Fond. "T.Campanella",
} Catanzaro 88900, Italy
After resective surgery of the pancreas, mean post-operative ICU stay and mean post-operative hospital stay were 7 and 20 days respectively; major post-operative complications were registered; 2 pts died in the post-operative period.

\section{Conclusions}

The overall outcome of pancreatic surgery in the elderly is acceptable; furthermore if we consider that it represents the only chance of cure in several pts with pancreatic disease we think that it should be offered also to elderly pts.

\section{Published: 19 May 2010}

\section{References}

1. Di Benedetto F, et al: Pancreatic Resections for Malignancy in patients aged 70 and older. Journal of the American Geriatrics Society 2009, 57(7):1323-1324.

2. Ballarin $R$, et al: Do not deny pancreatic resection to elderly patients. J Gastrointest Surg 2009, 13(2):341-348.

3. Hwang Sang II, et al: Surgical palliation of unresectable pancreatic head cancer in elderly patients. World J Gastroentero/ 2009, 15(8):978-982.

4. Hanada K: Current treatment strategies for pancreatic cancer in the elderly. Drugs Aging 2006, 23(5):403-410.

doi:10.1186/1471-2318-10-S1-A25

Cite this article as: Prati et al:: Pancreatic surgery in elderly patients. BMC Geriatrics 2010 10(Suppl 1):A25.

Submit your next manuscript to BioMed Central and take full advantage of:

- Convenient online submission

- Thorough peer review

- No space constraints or color figure charges

- Immediate publication on acceptance

- Inclusion in PubMed, CAS, Scopus and Google Scholar

- Research which is freely available for redistribution

Submit your manuscript at www.biomedcentral.com/submit

\section{Biomed Central}

